\title{
Dalton Trans
}

\section{COMMUNICATION}

\section{Isomerisation, Reactivity and Coordination Chemistry of a New Hybrid, Multi-functional Phosphazane}

Received 00th January 20xx, Accepted 00th January 20xx

DOI: $10.1039 / x 0 x \times 00000 x$

\section{www.rsc.org/}

The unsymmetric $P^{\prime \prime \prime} / P^{V}$ cyclodiphosphazane framework $\left[(\mathrm{S}=)(\mathrm{H}) \mathrm{P}\left(\mu-\mathrm{N}^{t} \mathrm{Bu}\right)_{2} \mathrm{PNH}^{t} \mathrm{Bu}\right]$ (2) provides entry into the mixed chalgogenide dianion $\left[(\mathrm{S}) \mathrm{P}\left(\mu-\mathrm{N}^{t} \mathrm{Bu}\right)_{2} \mathrm{P}(\mathrm{Se}) \mathrm{N}^{t} \mathrm{Bu}\right]^{2-}$, and unique insight into the mechanisms of cis/trans isomerism in phosph(III)and phosph(V)-azanes.

Establishing synthetic rules for the functionalisation and modification of ligand sets is a central subject in organic and inorganic chemistry. Adapting an established ligand allows easy control over the steric and electronic character in respect to coordination to metal centres. Much of our work has focused on the development of synthetic methodologies to inorganic ligand systems, which parallel developments in the organic arena. Phosph(III)azanes dimers have proved to be highly versatile building blocks in this area, being key starting materials for the construction not only of small multidentate ligand systems but also of large inorganic macrocycles. Highlighted in Figure 1 are two recent examples in which the phosphazane unit is used to construct $a$ ) a new type of hybrid carbene ligand, ${ }^{1}$ and $b$ ) a large macrocyclic arrangement. ${ }^{2,3}$ a)

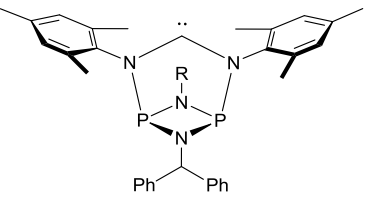

b)

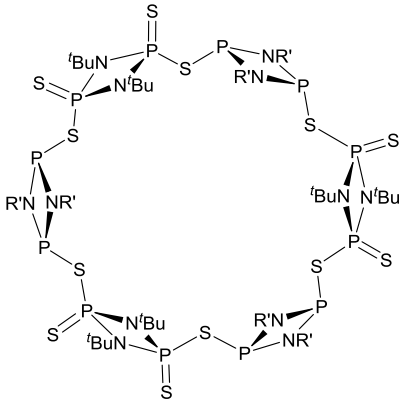

Figure 1 Examples of ligands derived from cyclodiphosphazane building blocks, a)

Chemistry Department, Cambridge University, Lensfield Road, Cambridge CB2 1EW (UK); e-maildsw1000@cam.ac.uk.

b. GIR MIOMeT-IU Cinquima-Química Inorgánica, Facultad de Ciencias, Campus Miguel, Delibes, Universidad de Valladolid 47011 Valladolid, Spain. e-mail raul.garcia.rodriguez@uva.es.

Electronic Supplementary Information (ESI) available: Contains synthetic details,

${ }^{1} \mathrm{H},{ }^{31} \mathrm{P},{ }^{77} \mathrm{Se} N \mathrm{MR}$ and $\mathrm{X}$-ray analysis on all compounds. See

DOI: $10.1039 / x 0 \times x 00000 x$ a modified carbene ligand and b) a PIII/PV macrocycle.

One area of particular interest has been the uncovering of new synthetic methods for the selective donor-functionalisation of the $\mathrm{P}_{2} \mathrm{~N}_{2}$ frameworks of cyclodiphosphazanes. A particularly important family in this class are the isoelectronic ligand systems shown in Figure 2, all of which can be readily accessed from nucleophilic substitution and/or oxidation of simple dichloro-phosphazanes $[\mathrm{CIP}(\mu-\mathrm{NR})]_{2}$ (e.g., Scheme 1).

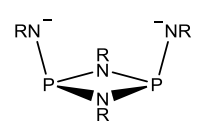

Stahl $^{4}$

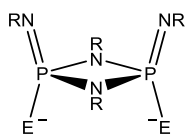

Chivers $^{5}$

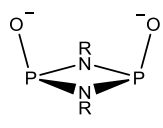

Wright $^{6}$

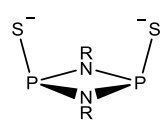

Wright $^{7}$
Figure 2 A series of isoelectronic multidentate dianionic ligands derived from nucleophilic substitution and/or oxidation of simple dicyclophosphazanes.<smiles>ClP1NP2NP(Cl)P12</smiles>

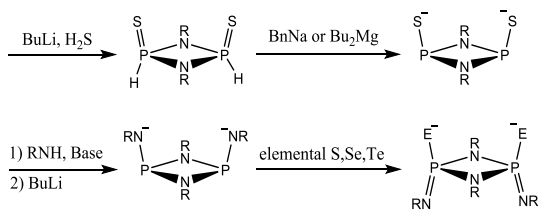

Scheme 1 Nucleophilic (top) $)^{8}$ and oxidative (bottom) $)^{9}$ functionalisation of a cyclodiphosphazane ring unit.

In the current study we set out with the simple aim of combining the previously established nucleophilic and oxidation reactions used in $\mathrm{P}_{2} \mathrm{~N}_{2}$-functionalisation (illustrated in Scheme 1) to obtain the first examples of unsymmetric hybrid frameworks based on the diphosph(III/V)azane unit (Scheme 2). With these new arrangements in hand, we are able to observe direct evidence of the type of mechanism involved in cis/trans isomerisation (inter- or intra-molecular), as well as develop new ligand chemistry based on these multifunctional donor systems. 
<smiles>[S-]p1[nH]p2[nH]p([S-])p1[nH]2</smiles>
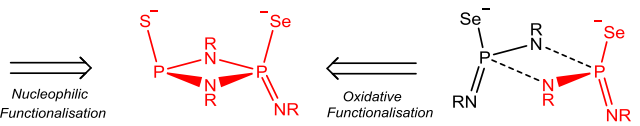

Scheme 2 Combining nucleophilic and oxidative functionalisation to produce hybrid ligands.

Synthetic studies started with the previously known unsymmetric cyclodiphosphazane $\left[\mathrm{ClP}\left(\mu-\mathrm{N}^{t} \mathrm{Bu}\right)_{2} \mathrm{PNH}^{t} \mathrm{Bu}\right]$ (1), which can be conveniently prepared on a multigram scale by the reaction of $\mathrm{PCl}_{3}$ with ${ }^{\mathrm{t}} \mathrm{BuNH}_{2}$ in $1: 6$ stoichiometric ratio (the excess ${ }^{t} \mathrm{BuNH}_{2}$ acting as a Bronsted base to scavenge $\mathrm{HCl}$ ). 1 was then reacted with a solution of LiSH in THF, prepared by the previously established procedure from the reaction of $\mathrm{H}_{2} \mathrm{~S}$ gas with ${ }^{n} \mathrm{BuLi}$ in THF. ${ }^{8}$ In situ ${ }^{31} \mathrm{P}\left\{{ }^{1} \mathrm{H}\right\}$ spectroscopy showed complete conversion of $\mathbf{1}$ into the product $[(\mathrm{S}=)(\mathrm{H}) \mathrm{P}(\mu$ $\left.\mathrm{N}^{t} \mathrm{Bu}\right)_{2} \mathrm{PNH}^{t} \mathrm{Bu}$ ] (2-trans) after $1 \mathrm{~h}$ at room temperature in $\mathrm{THF}$, as indicated by the upfield shift of the $\mathrm{P}^{\mathrm{III}}(\mathrm{P}-\mathrm{Cl})$ resonance in 1 (d., $\delta=201.2 \mathrm{ppm}$ ) to the $\mathrm{P}^{\mathrm{V}}[\mathrm{P}(\mathrm{H})(=\mathrm{S})]$ centre in 2-trans (d., $\delta=$ $\left.51.6 \mathrm{ppm},{ }^{2} J_{\mathrm{P}-\mathrm{P}}=5.45 \mathrm{~Hz}\right)$, and the retention of the $\mathrm{P}^{\mathrm{III}}-\mathrm{N}(\mathrm{H})^{t} \mathrm{Bu}$ group [ $\delta=136.1 \mathrm{ppm}$ in 1; cf $\delta=130.0 \mathrm{ppm}(\mathrm{br})$ in 2-trans] (see ESI). In the fully-coupled ${ }^{31} \mathrm{P} N \mathrm{NMR}$ spectrum, the $\mathrm{P}^{\mathrm{V}}$ $[\mathrm{P}(\mathrm{H})(=\mathrm{S})]$ resonance is observed as a double-doublet $\left({ }^{2} J_{\mathrm{PP}}=\right.$ $5.45 \mathrm{~Hz},{ }^{1} J_{\mathrm{PH}}=531.5 \mathrm{~Hz}$ ). Compound 2-trans can be isolated as a crystalline solid in $63 \%$ yield after removal of the reaction solvent and crystallisation from toluene (see ESI). Further confirmation of the presence of a $\mathrm{P}-\mathrm{H}$ proton and the retention of the $\mathrm{N}-\mathrm{H}$ proton in 2-trans comes from the ${ }^{1} \mathrm{H}$ NMR spectrum of the isolated material, with the $\mathrm{P}-\mathrm{H}$ proton appearing as a double-doublet $\left({ }^{1} J_{\mathrm{P}-\mathrm{H}}=531 \mathrm{~Hz},{ }^{2} J_{\mathrm{P}-\mathrm{P}}=9.8 \mathrm{~Hz}\right)$ and the $\mathrm{N}-\mathrm{H}$ proton as a broad singlet ( $\delta=2.56 \mathrm{ppm}$ ) (see ESI).

Figure 3 shows that the solid-state structure of 2-trans obtained under these conditions has a 'trans' arrangement, in which the ${ }^{t} \mathrm{BuNH}$ group and $\mathrm{S}$ atom are on opposite faces of the $\mathrm{P}_{2} \mathrm{~N}_{2}$ ring unit. Noteworthy features of this arrangement are the disposition of the ${ }^{t} \mathrm{BuNH}$ group exo to the $\mathrm{P}_{2} \mathrm{~N}_{2}$ ring fragment (presumably to avoid steric congestion with the $\mu$ $\mathrm{N}^{t} \mathrm{Bu}$ groups) and the planar conformation of the $\mathrm{P}_{2} \mathrm{~N}_{2}$ ring.

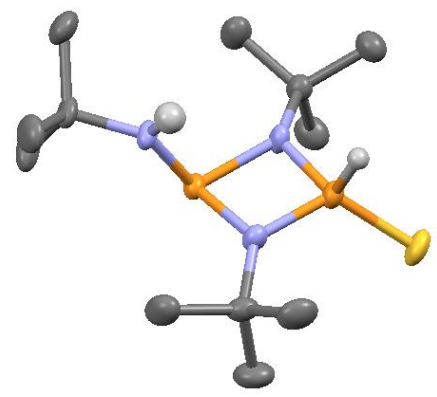

Figure 3 The structure of 2-trans. $\mathrm{H}$-atoms, except $\mathrm{N}-\mathrm{H}$ and $\mathrm{P}-\mathrm{H}$, have been omitted for clarity. Thermal ellipsoids are drawn at the $50 \%$ probability level. Selected bond lengths ( $\AA$ ) and angles ( $\left.{ }^{\circ}\right)$ : $\mathrm{P}(1)-\mu-\mathrm{N}^{t} \mathrm{Bu}$ range 1.648(3)-1.654(3), $\mathrm{P}(1)-\mathrm{S}(1)$ 1.942(1), $\mathrm{P}(2)-\mu-\mathrm{N}^{t} \mathrm{Bu}$ range 1.757(3)-1.761(3), $\mathrm{P}(2)-\mathrm{N}(\mathrm{H})^{t} \mathrm{Bu} 1.649(3)$, $\mathrm{N}^{t} \mathrm{Bu}-\mathrm{P}(1)-\mathrm{N}^{t} \mathrm{Bu}$ 85.4(1), $\mathrm{N}^{t} \mathrm{Bu}-\mathrm{P}(2)-\mathrm{N}^{t} \mathrm{Bu}$ 79.1(1), $\mathrm{P}(1)-\mu-\mathrm{N}^{t} \mathrm{Bu}-\mathrm{P}(2)$ range 97.4(1)$97.8(1)$

Heating a sample of isolated 2-trans to $50^{\circ} \mathrm{C}$ in THF for $16 \mathrm{~h}$ leads to complete conversion to $\mathbf{2}$-cis. The isomerisation of $\mathbf{2}$ is signalled by the upfield shifts in the $\mathrm{P}^{\mathrm{III}}$ and $\mathrm{P}^{\mathrm{V}}{ }^{31} \mathrm{P}\left\{{ }^{1} \mathrm{H}\right\} \mathrm{NMR}$ resonances, to $\delta=104.0\left[\mathrm{~d},{ }^{2} J_{\mathrm{P}-\mathrm{P}}=11.1 \mathrm{~Hz}, \mathrm{P}(\mathrm{III})\right]$ and $37.2 \mathrm{ppm}$ $\left(\mathrm{d},{ }^{2} J_{\mathrm{P}-\mathrm{P}}=11.1 \mathrm{~Hz}, \mathrm{P}(\mathrm{V})\right]$ in 2-cis, from those in 2-trans $(\delta=$ 130.0 and $51.6 \mathrm{ppm}$, respectively). 2-cis can be crystallised from the reaction in $85 \%$ yield (see ESI). The solid-state structure is shown in Figure 4. The metric parameters in 2 trans and 2-cis are very similar. Significantly, there is little or no distortion of the $\mathrm{P}_{2} \mathrm{~N}_{2}$ ring units of 2-trans and 2-cis, which are both almost planar. This can be compared to symmetric cyclo-diphosphazanes of the type $\left[R^{\prime} P(\mu-N R)\right]_{2}$, where the trans isomers have puckered ring units and the cis isomers have planar ring units. ${ }^{4}$ To the best of our knowledge, there is only one other example in which the solid-state structures of both the cis and trans isomers of an individual cyclodiphosphazane have been reported, $\left[(\mathrm{PhCC}) \mathrm{P}\left(\mu-\mathrm{N}^{t} \mathrm{Bu}\right)\right]_{2} .{ }^{10}$

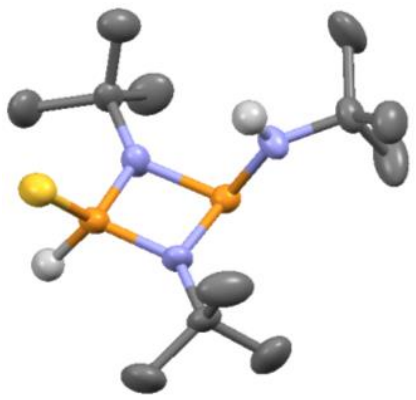

Figure 4 The structure of 2-cis. $\mathrm{H}$-atoms, except $\mathrm{N}-\mathrm{H}$ and $\mathrm{P}-\mathrm{H}$, have been omitted for clarity. Only one of the two crystallographically-independent molecules is shown. Thermal ellipsoids are drawn at the $50 \%$ probability level. Selected bond lengths $(\AA)$ and angles $\left({ }^{\circ}\right)$ : $\mathrm{P}^{\prime \prime \prime}-\mu-\mathrm{N}^{t} \mathrm{Bu}$ range $1.650(5)-1.742(5), \mathrm{P}^{\prime \prime \prime}-\mathrm{N}(\mathrm{H})^{t} \mathrm{Bu}$ range 1.638(6)-1.666(6), $\mathrm{P}^{\mathrm{V}}-\mu-\mathrm{N}^{t} \mathrm{Bu}$ range 1.645(6)-1.753(5), ), $\mathrm{P}^{\mathrm{V}}-\mathrm{S}(1)$ range 1.918(2)1.918(3), $\mathrm{N}^{t} \mathrm{Bu}-\mathrm{P}^{\prime \prime \prime}-\mathrm{N}^{t} \mathrm{Bu}$ range 79.0(3)-79.5(3), $\mathrm{N}^{t} \mathrm{Bu}-\mathrm{P}^{\mathrm{V}}-\mathrm{N}^{t} \mathrm{Bu}$ range $84.8(3)-$ 85.4(3), $\mathrm{P}^{\prime \prime \prime}-\mu-\mathrm{N}^{t} \mathrm{Bu}-\mathrm{P}^{\mathrm{V}}$ range $97.5(3)-98.2(3)$.

Three potential isomerisation mechanisms have been proposed for cylclo-diphosphazanes: (route a) (vertex) lonepair inversion at the P-centres, (route $b$ ) (edge) inversion at the bridging imido- $\mathrm{N}$ atoms, and (route $c$ ) cyclo-reversion followed by recombination $\left(2+2\right.$ cycloaddition) of the monomer units. ${ }^{4}$ While 2-trans was too thermally unstable to investigate the kinetics of its cis/trans isomerisation further (prolonged heating in THF led to a complicated mixture of decomposition products), it is clear from the quantitative conversion of 2trans to 2 -cis in $\mathrm{THF}$ at $50^{\circ} \mathrm{C}$ that the process cannot involve intermolecular cyclo-reversion, otherwise the symmetrical phosphazane products would also be observed (Scheme 3).

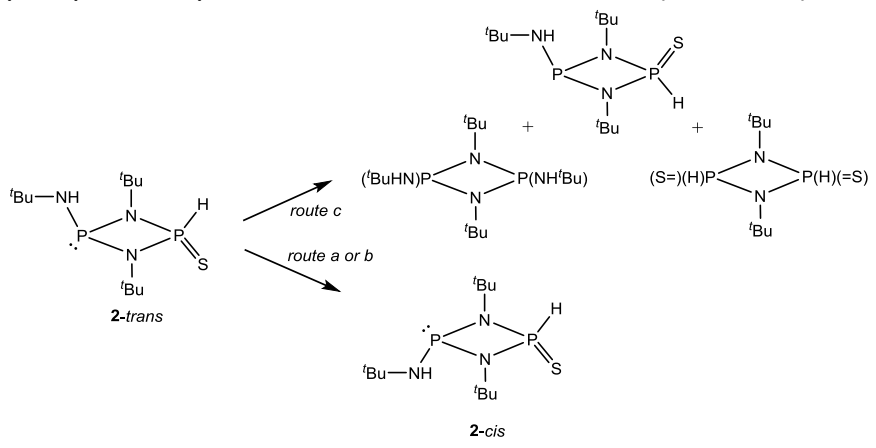

Scheme 3 Comparison of the products formed by (route $c$ ) intermolecular cycloreversion (top), and (routes $a$ or $b$ ) intramolecular vertex or edge inversion (bottom). 
The in situ ${ }^{31} \mathrm{P}\left\{{ }^{1} \mathrm{H}\right\}$ NMR spectrum of the reaction of 2-trans with elemental selenium in toluene at room temperature consists of two doublets at $\delta=36.2\left[{ }^{2} \mathrm{~J}_{\mathrm{p}-\mathrm{p}}=14.2 \mathrm{~Hz}, \mathrm{P}(\mathrm{Se})\right]$ and $33.5 \mathrm{ppm}\left[{ }^{2} \mathrm{~J}_{\mathrm{P}-\mathrm{P}}=14.0 \mathrm{~Hz}, \mathrm{P}(\mathrm{S})\right]$ (both splitting into a doubledoublet in the fully-coupled spectrum) (see ESI). This product, $\left[(\mathrm{S}=)(\mathrm{H}) \mathrm{P}\left(\mu-\mathrm{N}^{t} \mathrm{Bu}\right)_{2} \mathrm{P}(=\mathrm{Se}) \mathrm{NH}^{t} \mathrm{Bu}\right] \quad(3 \mathrm{a})$, can be isolated as a powder in $94 \%$ yield after filtration and removal of the solvent under vacuum (see ESI). The ${ }^{77}$ Se NMR spectrum of isolated 3a in $\mathrm{CDCl}_{3}$ shows a doublet $\left({ }^{1} J_{\mathrm{P}-\mathrm{Se}}=560.6 \mathrm{~Hz}\right)$, consistent with the oxidation of 2-trans at its $\mathrm{P}^{\text {III }}$ centre (see ESI). The solid-state structure of $\mathbf{3 a}$ shows that the oxidation of $\mathbf{2}$-trans is stereoselective, with retention of the trans-configuration of the ${ }^{t} \mathrm{BuN}(\mathrm{H})$-group and $\mathrm{S}$-atom (Figure 5). Like 2-cis and 2trans, the $\mathrm{P}_{2} \mathrm{~N}_{2}$ ring unit in $\mathbf{3 a}$ is almost completely planar; however, an interesting difference is found in the endoorientation of the ${ }^{t} \mathrm{BuNH}$-group with respect to the $\mathrm{P}_{2} \mathrm{~N}_{2}$ ring (cf. the exo disposition in 2-trans and 2-cis). Since there are no intermolecular $\mathrm{N}-\mathrm{H} \cdots \mathrm{S}$ or $\cdots . \mathrm{Se}$ interactions occurring in the lattice, it appears that this is due to the steric influence of the Se atom now bonded to the P-centre.

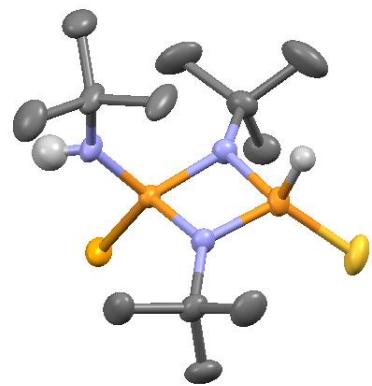

Figure 5 The structure of 3a. $\mathrm{H}$-atoms, except $\mathrm{N}-\mathrm{H}$ and $\mathrm{P}-\mathrm{H}$, have been omitted for clarity. Only one of the two independent molecules is shown. Thermal ellipsoids are drawn at the $50 \%$ probability level. Selected bond lengths $(\AA)$ and angles ( ${ }^{\circ}$ ): $\mathrm{P}_{s}-\mu-\mathrm{N}^{t} \mathrm{Bu}$ range 1.674(4)-1.678(4), $\mathrm{P}_{s}-\mathrm{S}$ 1.926(2)-1.930(2), $\mathrm{P}_{s}-\mu-\mathrm{N}^{t} \mathrm{Bu}$ range 1.685(4)-1.698(3), $\mathrm{P}_{s e}-\mathrm{N}(\mathrm{H})^{t} \mathrm{Bu}$ 1.627(4)-1.630(4), $\mathrm{P}_{s e}$-Se 2.090(1)-2.099(1), $\mathrm{N}^{t} \mathrm{Bu}-\mathrm{P}-\mathrm{N}^{t} \mathrm{Bu}$ 83.0(2)-84.2(2), $\mathrm{P}_{S e}-\mu-\mathrm{N}^{t} \mathrm{Bu}-\mathrm{P}_{s}$ range 95.8(2)-96.3(2). The $\mathrm{P}$ and $\mathrm{N}$ atoms of the $\mathrm{P}_{2} \mathrm{~N}_{2}$ ring unit are only deviated $c a .5 .7^{\circ}$ out of the plane.

Unlike 2, 3a is thermally stable in solution for prolonged periods, allowing the investigation of its isomerisation. Figure 6 shows the changes observed in the ${ }^{31} \mathrm{P}\left\{{ }^{1} \mathrm{H}\right\}$ NMR spectrum of $\mathbf{3 a}$ upon heating a sample in $d_{8}$-toluene over the temperature range $40-90{ }^{\circ} \mathrm{C}$. Heating to $40{ }^{\circ} \mathrm{C}$ for $24 \mathrm{~h}$ results in the appearance of two new resonances at $\delta=29.7\left[\mathrm{~d},{ }^{2} \mathrm{JPP}_{\mathrm{PP}}=9.8 \mathrm{~Hz}, \mathrm{P}(\mathrm{Se})\right]$ and $22.9 \mathrm{ppm}[\mathrm{d}$, ${ }^{2} J_{\mathrm{PP}}=8.4 \mathrm{~Hz}, \mathrm{P}(\mathrm{S})$ ] [cf. $3 \mathrm{a} \delta=36.2\left(\mathrm{~d},{ }^{2} \mathrm{~J}_{\mathrm{P}-\mathrm{P}}=14.2 \mathrm{~Hz}, \mathrm{P}(\mathrm{Se})\right), 33.5 \mathrm{ppm}$ $\left.\left(\mathrm{d}, \mathrm{P}(\mathrm{S}),{ }^{2} J_{\mathrm{P}-\mathrm{P}}=14.0 \mathrm{~Hz}\right)\right]$. The ${ }^{31} \mathrm{P}\left\{{ }^{1} \mathrm{H}\right\}$ chemical shift in $\mathbf{3 b}$ is similar to that reported for $\left.c i s-\left[{ }^{t} \mathrm{BuNH}\right)(\mathrm{Se}) \mathrm{P}\left(\mu-\mathrm{N}^{t} \mathrm{Bu}\right)\right]_{2} \quad(\delta=26.7 \mathrm{ppm}) .{ }^{9 a}$ Additional information comes from the ${ }^{1} \mathrm{H}$ NMR spectrum of the solid reaction products in $\mathrm{CDCl}_{3}$ recovered after $3 \mathrm{~h}$ at $60{ }^{\circ} \mathrm{C}$, which shows the appearance of a new set of $\mathrm{P}-\mathrm{H}, \mathrm{N}-\mathrm{H}$ and ${ }^{t} \mathrm{Bu}$ resonances in the same relative ratio as that found in $3 a$, identifying this species (3b) as an isomer of $\mathbf{3 a}$, with the $\mathrm{S}$ and Se atoms trans rather than cis with respect to the $\mathrm{P}_{2} \mathrm{~N}_{2}$ ring unit (Scheme 4) (see ESI). The ${ }^{31} \mathrm{P}\left\{{ }^{1} \mathrm{H}\right\}$ NMR spectrum of the reaction of solid Se with the $\mathbf{2}$-cis in toluene also shows the formation of $\mathbf{3 b}$. However, unlike the reaction of 2-trans with Se which occurs smoothly at room temperature, a complicated mixture of products is produced at the higher reaction temperature required (at reflux).

In addition to the resonances for $\mathbf{3} \mathbf{b}$, a further singlet resonance is also apparent after $24 \mathrm{~h}$ at $40{ }^{\circ} \mathrm{C}(\delta=30.8 \mathrm{ppm})$. Further heating of the reaction to $90{ }^{\circ} \mathrm{C}$ for 7 days results in the exclusive formation of this species, the consumption of $\mathbf{3 a}$ and $\mathbf{3} \mathbf{b}$ and the precipitation of a white solid. The new species was identified as the previously reported symmetric cyclodiphosphazane $\left[\left({ }^{t} \mathrm{BuNH}\right)(\mathrm{Se}) \mathrm{P}\left(\mu-\mathrm{N}^{t} \mathrm{Bu}\right)\right]_{2}$ (4) (Scheme 4) on the basis of spectroscopic analysis (lit. ${ }^{31} \mathrm{P}\left\{{ }^{1} \mathrm{H}\right\}$ NMR $\delta=26.7 \mathrm{ppm}$ in THF) (see ESI). ${ }^{9 a}$ The formation of $\mathbf{4}$ supports the view that the isomerisation of $\mathbf{3 a}$ to $\mathbf{3} \mathbf{b}$ occurs (at least in part) by the intermolecular cyclo-reversion mechanism. Since the other product of this reaction, symmetric $\left[(\mathrm{S}=)(\mathrm{H}) \mathrm{P}\left(\mu-\mathrm{N}^{t} \mathrm{Bu}\right)\right]_{2}$ (5) (Scheme 4), is known to be thermally unstable, ${ }^{8}$ it is not surprising that this component is not observed in the final NMR spectrum (and is presumably the source of the white solid decomposition product).

(24h, $40^{\circ} \mathrm{C}$

Figure 6 The development of the in situ ${ }^{31} \mathrm{P}\left\{{ }^{1} \mathrm{H}\right\} \mathrm{NMR}$ spectrum of 3 a with time at 40 $90{ }^{\circ} \mathrm{C}$ in $d_{8}$-toluene.

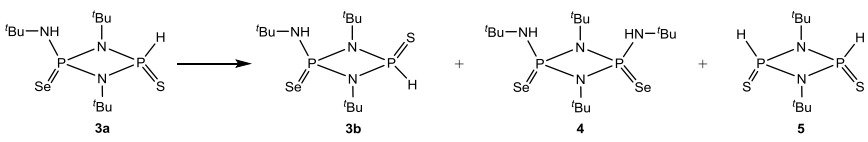

Scheme 4 The thermal isomerism of $\mathbf{3 a}$ to $\mathbf{3 b}$, with the formation of other potential products resulting from cyclo-reversion.

The kinetics of the conversion of $\mathbf{3} \mathbf{a}$ to $\mathbf{3} \mathbf{b}$ was followed by further NMR experiments. The relative integrals of the $\mathrm{P}-\mathrm{H}$ proton resonances were measured at a temperature of $50{ }^{\circ} \mathrm{C}$ for a total time of 588 mins, with NMR spectra being recorded every six mins (a total of 99 separate measurements). As can be seen from Figure 7 , the isomerisation of $\mathbf{3 a}$ to $\mathbf{3} \mathbf{b}$ follows first-order kinetics (with $R^{2}=0.994$ ). Our overall conclusion, drawn from these data and that shown in Figure 6, is that the isomerisation of $\mathbf{3 a}$ to $\mathbf{3 b}$ is probably largely via cycloreversion, in which the dissociation of $\mathbf{3 a}$ into two monomer units is rate determining. We cannot, however, exclude a contribution from intramolecular mechanisms (especially at lower temperatures). 


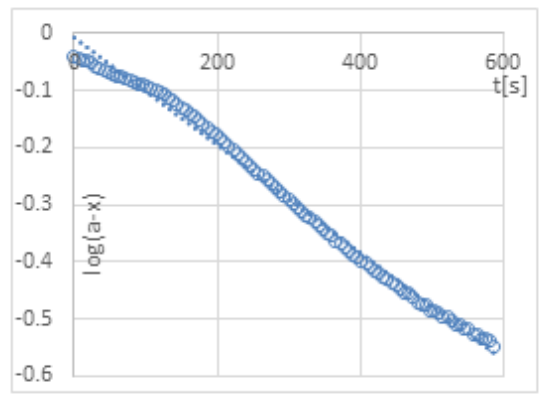

Figure $7 \mathrm{Graph}$ of the log of the concentration of $\mathbf{3 a}\left[(\mathrm{a}-\mathrm{x}) \mathrm{mol}^{-1}\right]$ at time $(\mathrm{t})$. The straight line is the best fit line, with $R^{2}=0.994$.

3a is readily deprotonated at both the $\mathrm{N}-\mathrm{H}$ and $\mathrm{P}-\mathrm{H}$ positions by reaction with benzylsodium ( 2 equiv.) in THF at room temperature. The $\mathrm{Na}$ complex $\left[\mathrm{Na}(\mathrm{THF}) \mathrm{Na}(\mathrm{THF})_{2.5}\{(\mathrm{~S}) \mathrm{P}(\mu-\right.$ $\left.\left.\left.\mathrm{N}^{t} \mathrm{Bu}\right)_{2} \mathrm{P}(\mathrm{Se}) \mathrm{N}^{t} \mathrm{Bu}\right\}\right](6)$ can be isolated in crystalline form after layering the reaction with $n$-hexane (in $24 \%$ yield) (see ESI). A polymeric arrangement is found for 6 in the solid state (Figure $8)$, in which the $\left[(\mathrm{S}) \mathrm{P}\left(\mu-\mathrm{N}^{t} \mathrm{Bu}\right)_{2} \mathrm{P}(\mathrm{Se}) \mathrm{N}^{t} \mathrm{Bu}\right]^{2-}$ dianion units are held together by alternating mono-THF solvated (fourcoordinate) $\mathrm{Na}^{+}$cations [ $\left.\mathrm{Na}(1)\right]$ by side-on $\mathrm{N} / \mathrm{Se}$ - and S-bonding on either side of the dianion. The other $\mathrm{Na}^{+}$cation $[\mathrm{Na}(2)]$ is solvated by three THF ligands, with one of the THF ligands disordered over coordinated and non-coordinated sites (ca. 50:50). This $\mathrm{Na}^{+}$cation is chelated by the $\mathrm{S}$ and $\mathrm{Se}$ atoms of the dianion (resulting in trigonal bipyramidal geometry). The large reduction in the exo- ${ }^{t} \mathrm{BuN}-\mathrm{P}[\mathrm{P}(2)-\mathrm{N}(3)$ 1.574(4) $\AA$ ] bond length compared to that in $3 a$ [cf. ca. $1.63 \AA$ ] reflects the increase in Zwitter-ionic character upon deprotonation. The retention of the original conformation of the ${ }^{t} \mathrm{BuN}$-group and $\mathrm{S}$ - and Seatoms upon deprotonation of $\mathbf{3 a}$ at room temperature is a particularly noteworthy feature of $\mathbf{6}$. Consistent with this conformational rigidity, if a mixture of isomers $\mathbf{3 a}$ and $\mathbf{3 b} \mathbf{b}(2$ : 1 ) is deprotonated with benzylsodium in THF both the cis- and the trans-[(S)P( $\left.\left.\mu-\mathrm{N}^{t} \mathrm{Bu}\right)_{2} \mathrm{P}(\mathrm{Se}) \mathrm{N}^{t} \mathrm{Bu}\right]^{2-}$ dianions are observed in solution (in the same $2: 1$ ratio as the starting materials).
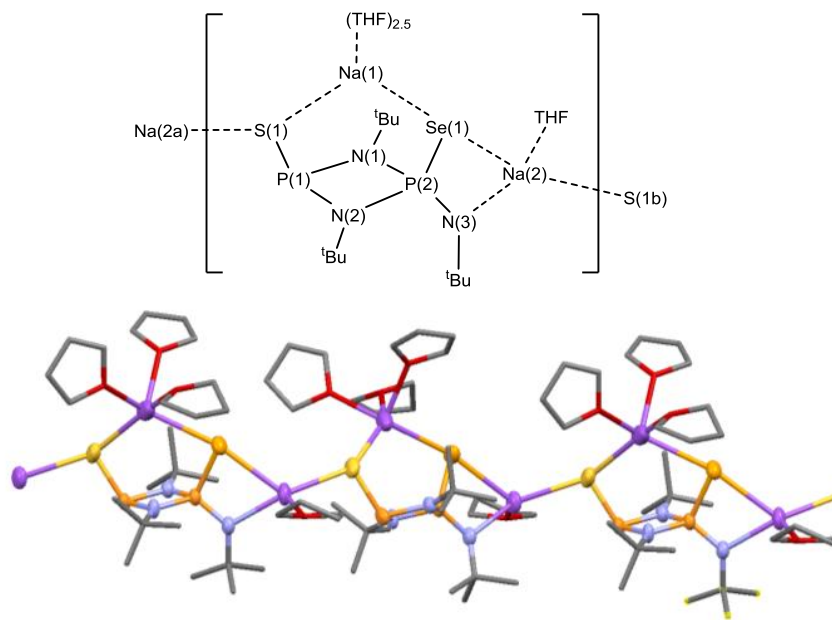

Figure 8 a) Connectivity and numbering scheme, and b) polymeric arrangement of 6 . $\mathrm{H}$-atoms have been omitted for clarity. The diagram shows all of the three THF ligand environments attached to $\mathrm{Na}(2)$, one of which is disordered over two 50:50 sites with the O-atom pointing towards the $\mathrm{Na}^{+}$cation and one THF environment in which the $\mathrm{O}$-atom points away from the $\mathrm{Na}^{+}$cation (see ESI).
Thermal ellipsoids are drawn at the $50 \%$ probability level for the heavy atoms, the THF ligands have been drawn as wire frames. Selected bond lengths ( $\AA$ ) and angles ( $\left.{ }^{\circ}\right)$ : $\mathrm{P}(1)-\mathrm{N}(1)$ 1.751(4), $\mathrm{P}(1)-\mathrm{N}(2)$ 1.746(3), $\mathrm{P}(1)-\mathrm{S}(1)$ 2.068(2), $\mathrm{P}(2)-\mathrm{N}(1)$ 1.693(3), $\mathrm{P}(2)-\mathrm{N}(2)$ 1.680(3), $\mathrm{P}(2)-\mathrm{N}(3)$ 1.574(4), $\mathrm{P}(2)-\mathrm{Se}(1)$ 2.187(1), Na(1)-S(1) 2.761(3), $\mathrm{Na}(1)-\mathrm{Se}(1)$ 2.894(2), Na(2)-Se(1) 2.924(2), Na(2)-N(3) 2.374(4), $\mathrm{Na}(2 \mathrm{a})-$ $\mathrm{S}(1)$ 2.790(2), $\mathrm{P}(1)-\mu-\mathrm{N}^{t} \mathrm{Bu}-\mathrm{P}(2)$ 98.4(2)-99.2(2), N(1)-P(1,2)-N(2) 79.4(2)-83.0(2), $\mathrm{Se}(1)-\mathrm{P}(2)-\mathrm{N}(3)$ 105.7(1).

In conclusion, by combining previously established synthetic approaches we have been able to build an

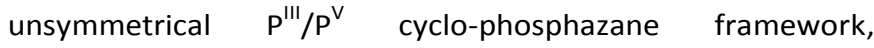
$\left[(\mathrm{S}=)(\mathrm{H}) \mathrm{P}\left(\mu-\mathrm{N}^{t} \mathrm{Bu}\right)_{2} \mathrm{PNH}^{t} \mathrm{Bu}\right](\mathbf{2})$. Both the cis and trans isomers of $\mathbf{2}$ have been structurally characterised, with the thermallyactivated cis/trans isomerisation following an intramolecular pathway. Further elaboration of this framework by oxidation of the $\mathrm{P}^{\prime \prime \prime}$ centre with Se gives the new $\mathrm{P}^{\mathrm{V}}$ species $[(\mathrm{S}=)(\mathrm{H}) \mathrm{P}(\mu$ $\left.\mathrm{N}^{t} \mathrm{Bu}\right)_{2} \mathrm{P}(=\mathrm{Se}) \mathrm{NH}^{t} \mathrm{Bu}$ ] (4), which also undergoes cis/trans isomerism in this case largely via a dissociative cyclo-reversion mechanism. Deprotonation of $\mathbf{4}$ gives the $[(\mathrm{S}) \mathrm{P}(\mu$ $\left.\left.\mathrm{N}^{t} \mathrm{Bu}\right)_{2} \mathrm{P}(\mathrm{Se}) \mathrm{N}^{t} \mathrm{Bu}\right]^{2-}$ dianion, the sodium salt of which is a potential starting material for transmetallation reactions with other main group and transition metals.

Acknowledgements We thank the EU (ERA Advanced Grant for DSW, Erasmus Programme KB), Cambridge Australia Scholarships and the Cambridge Trust (FJR), for funding and the Spanish MINECO-AEI and the European Union (ESF) for a Ramon y Cajal contract (RG-R, RYC-2015-19035).

\section{Notes and references}

1 T. Roth, V. Vasilenko, C. G. M. Benson, H. Wadepohl, D. S. Wright, L. H. Gade, Chem Sci., 2015, 6, 2506.

2 A. J. Plajer, R. García-Rodríguez, C. G. M. Benson, P. D. Matthews, A. D. Bond, S. Singh, L. H. Gade, D. S. Wright, Angew. Chem. Int. Ed., 2017, 56, 9087.

3 See also, T. Roth, H. Wadepohl, D. S. Wright, L. H. Gade, Chem Eur. J., 2013, 19, 13823; S. Gonzalez Calera and D. S. Wright, Dalton Trans., 2010, 39, 5055.

4 L. Stahl, Coord. Chem. Rev., 2000, 210, 203; M. S. Balakrishna, D. J. Eisler, T. Chivers, Chem. Soc. Rev., 2007, 36, 650; M. S. Balakrishna, Dalton Trans., 2016, 45, 12252.

5 R. Davies, L. Patel, Chalcogen-Phosphorus (and Heavier Congener) Compounds: Handbook of Chalcogen Chemistry: New Perspectives in Sulfur, Selenium and Tellurium, 2nd ed.; Devillanova, F. A.; du Mont, W-W., Eds.; RSC Publishing: UK, 2013; Vol. 1, Chapter 5, pp 238; A. Nordheider, J. D. Woolins, T. Chivers, Chem. Rev., 2015, 115, 10378.

6 W. T. K. Chan, F. García, S. Gonzalez-Calera, M. McPartlin, J. V. Morey, R. E. Mulvey, S. Singh, D. S. Wright, Chem. Commun., 2008, 2251.

7 C. G. H. Benson, A. Plajer, R. García-Rodríguez, A. D. Bond, S. Singh, L. H. Gade, D. S. Wright, Chem. Commun., 2016, 52, 9683.

8 C. G. M. Benson, V. Vasilenko, R. García-Rodríguez, A. D. Bond, S. G. Calera, L. H. Gade, D. S. Wright, Dalton Trans., 2015, 44, 14242

9 (a) T. Chivers, M. Krahn, M. Parvez, Chem. Commun., 2000, 463; (b) T. Chivers, M. Krahn, M. Parvez, G. Schatte, Inorg. Chem., 2001, 40, 2547.

10 M. M. Siddiqui, J. T. Mague, M. S. Balaskrishna, Inorg. Chem., 2015, 54, 1200. 